\title{
New Venture Formation: A Capability Configurational Approach
}

\author{
By Kamran Razmdoost, Leila Alinaghian and Christian Linder
}

\begin{abstract}
The formation of new ventures is affected by multiple, interrelated capabilities, resulting in configurations of capabilities. Adopting a configurational approach, our study aims to explore how various combinations of ventures' ordinary capabilities (i.e., resources and competencies), ventures' dynamic capabilities (i.e., sensing and seizing), and founders' dynamic managerial capabilities (i.e., human capital, social capital, managerial cognition) elucidate the successful formation of new ventures in both stable and dynamic environments. The results of a Qualitative Comparative Analysis of 299 solo-founded ventures reveal six capability configurations leading to new venture formation. In particular, we have identified four archetypes of ventures, the formations of which are shaped as a result of specific combinations of capabilities: capability driven, resource driven, bricoleur, and agile. Our configurational approach reveals that different ventures can achieve the same result through various unique combinations of capabilities.
\end{abstract}

\section{Keywords:}

Dynamic managerial capabilities, Dynamic capabilities, Ordinary capabilities, Venture formation, Configuration, QCA 


\section{New Venture Formation: A Capability Configurational Approach}

\section{Introduction}

The formation of new ventures is a key determinant of economic and societal developments (Hall, Daneke, \& Lenox, 2010; Wong, Ho, \& Autio, 2005). New venture formation (also termed new venture creation or new venture emergence) is a recursive and progressive process of identifying a new venture idea in an enabling environment, engaging in entrepreneurial activities such as acquiring resources and developing competencies, and evaluating the new venture idea, ultimately leading to the establishment of the new venture (Davidsson, 2015; Miozzo \& DiVito, 2018). There have been significant efforts in identifying and theorizing the factors that contribute to the formation of new ventures. For instance, extant studies have documented founders' human and social capital (Davidsson \& Honig, 2003; De Carolis, Litzky, \& Eddleston, 2009; Grichnik, Brinckmann, Singh, \& Manigart, 2014), venture resources (Mousa \& Reed, 2013; Wood \& William, 2014), and early planning (Dimov, 2010) as determinants of new venture formation.

Research has recently begun to recognize that these determinants do not work in isolation but rather interact with each other in forming the new venture (Linder, Lechner, \& Petzl, 2019). For instance, founders' human capital and social capital positively interact in affecting new venture formation (Semrau \& Hopp, 2016). Similarly, the effect of founders' human capital on subsequent resource acquisition (i.e., an entrepreneurial activity underpinning new venture formation) is positively moderated by the venture's initially acquired resources (Ko \& McKelvie, 2018). Furthermore, research has revealed that these determinants are often interrelated, in which one's observed conjunction with new venture formation may well be generated due to the presence of the other. For instance, Vilanova and Vitanova (2019) showed that the observed 
effect of founders' confidence on new venture formation is explained through founders' entrepreneurial activities.

Nonetheless, a systematic and comprehensive articulation of multiple, interrelated factors that determine new venture formation has yet to be attempted. Specifically, the literature has underestimated that new ventures can be successfully formed via the different combinations of factors (i.e., multiple configurations) and instead suggests that imitating best practice (as proposed in the form of a universal configuration) will always lead to the desired outcome (i.e., new venture formation). Therefore, a configurational approach (Meyer, Tsui, \& Hinings, 1993) is required to explore alternative combinations of factors that lead to new venture formation. This issue is salient in the context of new ventures, where the uniqueness of each venture's conditions often creates multiple configurations of capabilities (Wilden, Devinney, \& Dowling, 2016). In particular, research suggests that distinct managerial foresight (Laamanen \& Wallen, 2009), a venture's chosen growth path (Coad, Frankish, Roberts, \& Storey, 2013) and environmental conditions (Zahra, Sapienza, \& Davidsson, 2006) lead to distinctive profiles of capabilities. Although recent entrepreneurship studies have begun to adopt a configurational approach to identify multiple behavioral models of new ventures (e.g., causation and effectuation, Stroe, Parida, \& Wincent, 2018; Villani, Linder, \& Grimaldi 2018), they lack the identification of capability configurations leading to new venture formation.

Thus, drawing on a capability-based view of the firm (Helfat \& Martin, 2015; Zahra et al., 2006), our study aims to explore how various combinations of the ventures' ordinary capabilities (i.e., venture's ability to perform the basic functional activities to earn a living in the present, Winter, 2003), ventures' dynamic capabilities (i.e., venture's ability to change, update, and better utilize ordinary capabilities, Zollo \& Winter, 2002), and founders'dynamic managerial 
capabilities (i.e., founder's ability to create and modify venture's ordinary capabilities, Helfat \& Martin, 2015) elucidate the successful formation of new ventures. We use a Qualitative Comparative Analysis approach based on the logic of fuzzy sets technique, which allows the exploration of interactions among multiple capabilities, as well as the consideration of multiple plausible configurations leading to successful venture formation (Fiss, 2007; Ragin, 2008; Woodside, 2013).

Our study contributes to the entrepreneurship literature on several fronts. First, we extend an understanding of the role of ordinary, dynamic, and dynamic managerial capabilities in venture success (e.g., Lisboa, Skarmeas, \& Saridakis, 2016; Townsend \& Busenitz, 2015) by identifying alternative configurations of various components of these capabilities that lead to the formation of new ventures. Specifically, by investigating both ventures' ordinary and dynamic capabilities and founders' dynamic managerial capabilities, our study sheds critical light on how the interactions of founder and venture capabilities can lead to the formation of new ventures. Furthermore, we clarify the role of dynamic capabilities in new venture formation; this role is an understudied phenomenon in the entrepreneurial literature. Second, we explore alternative, new venture archetypes based on distinct combinations of ordinary, dynamic, and dynamic managerial capabilities, the capability development behavior of which may not be explained by existing entrepreneurship behavioral models (e.g., effectuation, causation, or bricolage, Welter, Mauer, \& Wuebker, 2016). Lastly, we investigate capability configurations in both stable and dynamic environments and advance understanding of the role of environmental dynamism in new venture formation. 


\section{Capabilities and new venture formation}

\subsection{Ordinary capabilities and new venture formation}

Ordinary capabilities are defined as a "firm's fundamental business" (Teece, Pisano, \& Shuen, 1997, p. 516) that deals with "the performance of administrative, operational and governance-related functions" (Teece, 2014, p. 328). These capabilities are a firm's bundle of resources and competencies that are employed in its operational activities (Wang \& Ahmed, 2007; Zollo \& Winter, 2002). Resources (also referred to as assets) are defined as "the stock of available factors that are owned or controlled by the firm", whereas competencies refer to a "firm's capacity to deploy resources" (Amit \& Schoemaker, 1993, p. 35). In the context of new ventures, the extant literature has identified various resources (e.g., technological and financial resources, Lee, Lee, \& Pennings, 2001) and competencies (e.g., business and marketing planning, Burke, Fraser, \& Greene, 2010; Gruber, 2007) that underpin the ongoing operations of these ventures.

Ordinary capabilities impact new venture formation both by enhancing the evaluation of a new venture idea and through generating a positive performance that will lead to subsequent resource acquisitions. First, a new venture idea (also referred to as a venture opportunity) as a fundamental determinant of new venture formation is closely linked to resources and competencies employed by the venture. A new venture idea is the imagined set of resources and competencies (e.g., the design of a product or service and processes delivering those products and services to the market) that have the potential to address an unmet need in the market (Ardichvili, Cardozo, \& Ray, 2003; Davidsson, 2015). Indeed, venture ordinary capabilities play a crucial role in shaping the founders' perception towards the new venture idea as the prerequisite of new venture formation (Ardichvili et al., 2003; Davidsson, 2015; Kor, Mahoney, 
\& Michael, 2007; Mousa \& Reed, 2013). Specifically, prior work has shown that the development of valuable resources (Haynie, Shepherd, \& McMullen, 2009; Wood \& Williams, 2014) and competencies (e.g., business activities planning) has a positive impact on new venture formation through enhancing founders' confidence in the viability of the venture (Dimov, 2010; Rasmussen, Mosey, \& Wright, 2011). In particular, through their experience of interacting with venture resources and competencies, founders would form a judgment that defines their evaluation of the new venture idea (Gruber, Kim, \& Brinckmann, 2015).

Second, the positive performance that results from the venture's ordinary capabilities can influence the progress of the new venture in the form of subsequent resource acquisition. The performance of new ventures has been attributed to a number of resources and competencies, such as human and financial assets (Samagaio \& Rodrigues, 2016), the growth path (Coad et al., 2013), and e-business capabilities (Bi, Davison, \& Smyrnios, 2017). Founders tend to communicate the initial venture performance to attract further resources and make progress towards forming the venture (Bammens \& Collewaert, 2014).

Scholars have suggested that resources and competencies have an interactive effect on a venture's performance. On the one hand, ventures need to have competencies to be able to extract benefits from their resources (Newbert, 2007). Alternatively, the performance of competencies is limited by the resources these ventures own or control (Ray, Barney, \& Muhanna, 2004). However, the interactive effects of these resources and competencies on new venture formation are yet to be articulated. Furthermore, it is not clear whether the presence of other forms of capabilities (i.e., dynamic capabilities or dynamic managerial capabilities) can compensate for the absence of ordinary capabilities in forming a new venture. Thus, what is 
required is a configurational approach that allows the investigation of different combinations of ordinary, dynamic, and dynamic managerial capabilities leading to new venture formation.

\subsection{Dynamic capabilities and new venture formation}

Dynamic capabilities are higher-order capabilities that enable firms to alter the way they make a living (Helfat \& Winter, 2011) in responding to, or sometimes creating, environmental changes (Teece, 2007; 2014). They are the firm's ability to integrate, build, and reconfigure their resources and competencies and, therefore, maintain performance in the face of changing business environments (Teece et al., 1997) (for an expanded notion, see Helfat et al., 2007; Teece, 2014). In particular, scholars have described the notion of dynamic capabilities based on a firm's capacity to continuously sense and seize new opportunities (Teece, 2007). Sensing activities include scanning, identifying, creating, anticipating, protecting, and disseminating potential opportunities (Benner \& Tushman, 2003; Wang \& Ahmed, 2007). Seizing involves planning the mobilization of resources to formulate a plausible response to the sensed trends by allocating the required resources and using prioritization tools (Benner \& Tushman, 2003). New ventures' dynamic capabilities to continuously identify new opportunities (e.g., identification of unmet needs, Amit \& Han, 2017) and update, expand, and create new ordinary capabilities (e.g., exploratory innovations, Kollmann \& Stöckmann, 2014) have been identified as the key determinants of new venture success (Rusmussen et al., 2011).

Dynamic capabilities exist in new ventures from their early stage of formation (Arend, 2014) and are associated with the venture's creation, discovery, and successful exploitation of opportunities (Zahra et al., 2006). Dynamic capabilities impact new venture formation through enhancing ordinary capabilities (Rusmussen et al., 2011). These capabilities reconfigure initial ordinary capabilities to generate new resources and competencies that can produce positively 
evaluated outcomes (Newbert, 2005). Specifically, dynamic capabilities help new ventures to generate valuable and unique ordinary capabilities in the market. For instance, sensing and seizing new product opportunities lead to the timely launch of high-quality, unique products in the market (Lisboa et al., 2016). Furthermore, when the changes in the environment are highly discontinuous, dynamic capabilities are required to a substantial degree for the simultaneous development of multiple competencies (Laamanen \& Wallin, 2009).

Furthermore, dynamic capabilities may drive new venture formation by enhancing the founders' evaluation of the new venture idea. Generally, founders follow a cause-and-effect chain to predict the future with respect to the venture's viability (Wood \& McKelvie, 2015). They may engage in causation processes, focusing on choosing means such as resources and competencies to achieve specific desired outcomes and/or effectuations processes, focusing on choosing between possible outcomes that can be created by given means (Sarasvathy, 2001). In stable environments, where causation processes are more likely to be followed, founders often evaluate the new venture idea based on the existing resources and competencies (i.e., ordinary capabilities), avoiding environmental changes (Jiang \& Tornikoski, 2019). However, in dynamic environments where founders engage in effectuation processes and leverage the existing environmental changes through a reconfiguration of their ordinary capabilities (Jiang \& Tornikoski, 2019), dynamic capabilities will play a more salient role in signaling the venture viability. Our study specifically seeks to clarify this role by exploring configurations of dynamic capabilities and different capability types that lead to a successful formation of new ventures.

\subsection{Founder dynamic managerial capabilities and new venture formation}

Founders have a crucial role in the process of new venture formation, from identifying the new venture idea and acquiring resources, to evaluating the viability of the venture and 
eventually establishing the new venture (Dimov, 2010; Nambisan \& Baron, 2013; Zahra et al., 2006). Specifically, the founders' capabilities on their own could lead to the successful formation of the venture. These capabilities can be categorized into human capital, social capital, and managerial cognition constituting the founders' dynamic managerial capabilities (i.e., the ability to create and modify a venture's ordinary resources, Helfat \& Martin, 2015; Townsend \& Busenitz, 2015). Whereas human capital refers to "the knowledge and skills that individuals bring to a task they set out to perform" (Dimov, 2010, p. 1129), social capital represents the ability to access benefits through social relationships (Davidsson \& Honig, 2003). Additionally, managerial cognition is defined as the individual's ability to perceive, attend, critically analyze and communicate new knowledge in different contexts (Helfat \& Peteraf, 2015). Thus, whereas human capital refers to the founder's existing capabilities, social capital reflects their access to external capabilities, and managerial cognition is associated with their ability to generate new capabilities.

Extant studies have illustrated that both human and social capital drive entrepreneurial activities underpinning new venture formation (e.g., resource acquisition and competency development, Davidsson \& Honig, 2003; De Carolis et al., 2009; Grichnik et al., 2014; Rotefoss \& Kolvereid, 2005; Samuelsson \& Davidsson, 2009; Townsend \& Busenitz, 2015). Indeed, founders generate the venture's required ordinary and dynamic capabilities either through their existing knowledge and experience or by accessing those capabilities in their network of relationships, a process that then leads to new venture formation (McKelvie \& Davidsson, 2009; Vilanova \& Vitanova, 2019). For instance, a founder's knowledge and skills (evaluated by their education and previous experiences) have a signaling effect on attracting the financial resources required to form a venture (Ko \& McKelvie, 2018). Furthermore, McKnight and Zietsma (2018) 
illustrated that the presence of human capital is necessary in commercialization processes, particularly when the new idea is completely novel in the market. Social capital also leads to a lower cost of acquiring external resources and competencies (Newbert \& Tornikoski, 2013). Semrau and Hopp (2016) further demonstrated that human and social capital have an interactive effect on entrepreneurial activities. The authors suggest that depending on the type of resources founders attract through their social capital, this interaction could be negative or positive. Indeed, founders with a high level of human capital make further progress with their entrepreneurial activities when they experience a strong acquisition of financial resources through their social capital. This process is reversed in the case of informational resources that provide complementary resources to founders with a lack of human capital and redundant resources to those founders possessing a high level of human capital.

Furthermore, human capital leads to opportunity recognition and increases founders' confidence and accuracy in their evaluation of the new venture idea as a key prerequisite to new venture formation (Ardichvili et al., 2003; Cassar, 2014). Drawing on a sample of solo nascent entrepreneurs from the Panel Study of Entrepreneurial Dynamics, Dimov (2010) showed that human capital (i.e., captured via founder experience) positively impacts new venture formation by enhancing confidence in the opportunity evaluation. Wood and Williams (2014) also illustrated that human capital moderates the relationship between new venture resources and the attractiveness of the new venture idea.

Although the role of human and social capital in new venture formation is documented in the literature, managerial cognition as a potential driver of formation has yet to be investigated. Managerial cognition is beyond the founders' cognitive capability in evaluating the new venture idea (Wood \& McKelvie, 2015) and involves the identification and configuration of new 
capabilities as well as the reconfiguration of existing ones (Helfat \& Peteraf, 2015). Managerial cognition can be manifested in the founders' ability to collect intelligence (Levine, Bernard, \& Nagel, 2017) and establish and engage with the networks of relationships (Huynh, Pattona, Arias-Arandab, \& Molina-Fernándezb, 2017). In fact, managerial cognition may compensate for the potential lack of human or social capital in forming new ventures. To assess the extent to which founders' managerial cognition accounts for new venture formation, our study seeks to identify configurations of dynamic managerial capabilities along with new venture ordinary and dynamic capabilities that lead to the formation of new ventures.

\subsection{Environmental dynamism}

The relative importance of ordinary, dynamic, and dynamic managerial capabilities for firm performance, in general, has been examined in light of environmental dynamism. For instance, extant studies have illustrated that environmental dynamism positively moderates the impact of dynamic capabilities on firms’ performance (Wilhelm, Schlömer, \& Maurer, 2015). Similarly, Barrales-Molina, Bustinza, and Gutiérrez-Gutiérrez (2013) illustrated that only managers who perceive environmental dynamism invest in dynamic capabilities. More recently, based on a meta-analysis of 115 studies, Karna, Richter, and Riesenkampff (2016) found that the performance effects of ordinary and dynamic capabilities are positive and similar in magnitude in both relatively stable and changing environments.

Environmental dynamism is an important contextual factor in defining how new ventures may benefit from their capabilities. For instance, scholars suggest that new ventures benefit more from dynamic capabilities in dynamic environments (Al-Aali \& Teece, 2014; Zahra et al., 2006). Previous studies have also identified different competencies for dynamic and stable environments. For instance, whereas new ventures benefit from strategic variety in highly dynamic industries 
(Larrañeta, Zahra, \& González, 2014), stable environments require more efforts towards the development of marketing plans (Gruber, 2007).

Nonetheless, it is still unclear how environmental dynamism plays a role in the relationship between capabilities and new venture formation. Townsend and Busenitz (2015) showed that the effect of dynamic managerial capabilities on resource acquisition is weakened in uncertain environments. However, this finding is yet to be corroborated in the presence of dynamic capabilities. Indeed, dynamic capabilities may be more important than ordinary resources as a determinant of new venture formation in dynamic environments, where ventures engage more in effectuation processes and need the ability to leverage environmental changes (Jiang \& Tornikoski, 2019). Hence, the lack of dynamic managerial capabilities may be compensated by the presence of dynamic capabilities in dynamic environments and vice versa. Furthermore, human capital, social capital, and managerial cognition, as well as different components of ordinary and dynamic capabilities, may have different functions in stable and dynamic environments. Our study thus seeks to clarify these issues by identifying configurations of various components of ordinary, dynamic, and dynamic managerial capabilities that lead to new venture formation in both stable and dynamic environments (see Figure 1).

\section{INSERT FIGURE 1 ABOUT HERE}

\section{Methods}

We assess the extent to which ordinary, dynamic, and dynamic managerial capabilities account for the formation of a new venture by applying fuzzy-set Qualitative Comparative Analysis (QCA) (Ragin, 2008), a method that is in line with our prior theorizing (i.e., various interconnected configurations of distinct capabilities explain new venture formation better rather than selected and isolated capabilities). 


\subsection{Data collection and case selection}

We used data from CAUSEE (Comprehensive Australian Study of Entrepreneurial Emergence), an Australian longitudinal data set (2007-2013), which follows nascent and young ventures over a 6-year period through successive interview waves (see Davidsson, Steffens, \& Gordon (2011) for a detailed elaboration of the dataset). CAUSSE contains 1,998 cases (obtained from a screening sample of 30,430 randomly selected households in the first year). The chosen dataset allowed direct investigation of founders and ventures' capabilities, where data were collected on entrepreneurial activities (i.e., the actions that a founder may take such as building a team, getting in contact with potential customers, bootstrapping necessary financial resources to exploit a recognized opportunity), founders and ventures' characteristics, venture formation, venture activities, as well as outcome information on venture performance such as sales or revenues. Thus, CAUSEE circumvents the negative influence of survivorship or recall biases.

We chose the founder as our level of analysis. In particular, we used data from the nascent stage until the establishment of the venture. We only included founders who worked full time for the venture in an attempt to make a living from the new business to eliminate the bias resulting from hobbyists starting their business with low intensities (Reynolds, 2017). Additionally, to achieve a comparable sample, we focused on solo founders exclusively and omitted group or team start-ups at this stage of the analysis (Davidsson \& Wiklund, 2001). Our sample comprises 299 cases of solo founders. Table 1 provides the descriptive statistics that, in line with comparable entrepreneurship studies, support our assumption of an unbiased sample.

INSERT TABLE 1 ABOUT HERE 


\subsection{Conditions and calibration}

The Boolean logic of QCA requires assigning cases' membership scores in sets that denote founders' (and the associated ventures') attributes to variables of interest. This step is referred to as calibration, and the attributes and variables used in the calibration process are hereafter termed conditions (Fiss, 2007; McKnight \& Zietsma, 2018). The specific measurement items for outcome and explanatory conditions are detailed in Appendix A.

\subsubsection{Outcome condition}

New venture formation involves the identification of a new venture idea, entrepreneurial activities, evaluation of the new venture idea, as well as the formal establishment of the new venture (Davidsson, 2015; Miozzo \& DiVito, 2018). New venture formation, as a recursive and multifaceted concept, is a complex phenomenon, where its operationalization has relied on a wide range of activities (e.g., Dimov, 2010; Vilanova \& Vitanova, 2019). However, early activities of a new venture may themselves drive the venture formation rather than represent the outcome. For instance, whereas organizing activities are investigated as a driver of venture formation in some studies (e.g., Lichtenstein, Carter, Dooley, \& Gartner, 2007), others have used these activities to indicate new venture formation itself (e.g., Vilanova \& Vitanova, 2019). Therefore, our study seeks to operationalize new venture formation via an activity that occurs in the later stages of new venture formation. Consistent with Qin, Wright, and Gao (2017), we used the legal establishment of the venture as an important milestone concluding the new venture formation process (i.e., hereafter FORM, coded binary). Indeed, our outcome differentiates between those entrepreneurs who were able to transfer their business idea into a legal business and those terminating their ambition. We further took into account that entrepreneurs give up 
their search for opportunities for reasons other than failure (Khelil, 2016). Hence, we excluded cases of involuntary termination.

\subsubsection{Explanatory conditions: founder dynamic managerial capabilities}

Founders' dynamic managerial capabilities were operationalized in terms of human capital (HUM), social capital (SOC), and managerial cognition (COG). Building on existing studies (e.g., Delmar \& Shane, 2004; Rauch \& Rijsdijk, 2013; Shane \& Stuart, 2002; Unger, Rauch, Frese, \& Rosenbusch, 2011), we borrowed measurement items to represent both general and specific human capital including 1) education (highest degree obtained), 2) parental start-up experience (the founder grew up in a family with parents as active entrepreneurs), 3) managerial experience, 4) industry experience, and 5) start-up experience. Further, social capital is assessed as the value embedded in a set of social relationships with individuals or collectives (Adler \& Kwon, 2002). We operationalized social capital in terms of the effective use of external partners (helper) and internal supporters (family and friends) in forming the venture (Stam, Arzlanian, \& Elfring, 2014). Finally, the founders' managerial cognition was measured by four items depicting their networking, advice-seeking, and training activities. This approach is in line with our conceptualization of managerial cognition as an ability to collect intelligence (Levine et al., 2017) and engage in a network of relationships (Huynh et al., 2017).

\subsubsection{Explanatory conditions: venture ordinary and dynamic capabilities}

We measured ordinary capabilities in terms of resources (RES) and competences (COM) (Amit \& Schoemaker, 1993). We considered resources that underpin the design, production, delivery, and marketing of venture products or services (e.g., Danneels, 2008; Kaleka, 2002). Specifically, we used four items representing resources contributing to the identification of product/service offerings and target markets, as well as their sourcing and producing, and selling 
and promotion. Additionally, competencies were categorized into supply-oriented, marketoriented, and organizational processes (e.g., Danneels, 2008; Kaleka, 2002). We used four items to measure processes enhancing supplier or customer engagement with the venture (i.e., supplyand market-oriented competencies). We further measured organizational competencies through two items representing the venture business planning process as the core indicator of organizational competencies in nascent ventures (Burke et al., 2010). Our approach in measuring resources and competencies covers the five categories of product or service, assets, operations and processes, relationship building, and organization suggested by the extant studies operationalizing ordinary capabilities (e.g., Drnevich \& Kriauciunas, 2011; Karna et al., 2016).

Dynamic capabilities were measured using two clusters of activities: identification and assessment of an opportunity (sensing, $S E N$ ) and mobilization of resources to address an opportunity and to capture value from doing so (seizing, SEI) (Teece, 2007). We measured sensing through four items representing the extent to which new ventures have identified regulatory-, customer-, competitor-, and market-related opportunities. Seizing capabilities were measured by four items at the extent to which there have been changes in product/service offerings, target markets, sourcing/producing, and selling/promotion activities. Changes are an indication of a firm's ability to seize an opportunity and adjust its actions accordingly (David, Sine, \& Haveman, 2013) (see Appendix A).

\subsubsection{Context condition: environmental dynamism}

We identified dynamic and stable environments by using an industry-based measure of environmental dynamism (e.g., Karna et al., 2016). We adapted Girod and Whittington's (2017) operationalization of environmental dynamism based on Dess and Beard's (1984) widely used industry-based environmental dynamism measure. Specifically, we applied a modified version of 
their method, where we considered environmental dynamism as the rate of change made to the initial business idea in each industry. We identified industries with a relatively higher (lower) rate of change to represent dynamic (stable) environments. The rate of changes in industries ranges from 0.00 to 2.67 , with a mean of 1.421 and a standard deviation of 0.346 . We used the median as a cut-off value to separate stable from dynamic industries, leading to 137 and 162 cases in stable and dynamic environments, respectively.

\subsubsection{Data calibration}

QCA treats the conditions (HUM, SOC, COG, RES, COM, SEI, and SEI) that lead to an outcome (FORM) as a set, with each case in the dataset having a set membership. Table 2 provides an overview of our calibration process as well as the thresholds used for set memberships. We applied a calibration technique, suitable for quantitatively large N-samples (Cooper \& Glaesser, 2016), that follows the data structure (i.e., binary data) for crisp sets and relies on distribution parameters for fuzzy sets. To calibrate our outcome condition (FORM), we applied crisp sets, differentiating those entrepreneurs who made the step to register a formal venture from those giving up their venture idea. We further applied fuzzy sets to calibrate our explanatory conditions. For these conditions, we used the $75^{\text {th }}$ percentile for each measure as the threshold for obtaining full set membership. Cases in the $25^{\text {th }}$ percentile were also considered to qualify for a fully out set membership. The remaining cases were neither fully in nor fully out (a crossover point of maximum ambiguity regarding membership) (Fiss, 2011; Misangyi et al., 2017).

INSERT TABLE 2 ABOUT HERE

Because the calibration threshold is critical to building robust sets and subsequent analysis (Glaesser \& Cooper, 2014), we performed several operations to ensure the validity of our 
threshold. In particular, we followed common recommendations for avoiding errors in data calibration (e.g., Ragin, 2008; Maggetti \& Levi-Faur, 2013). For instance, we looked for natural breaks in data distributions. Specifically, we used several distribution factors to detect nonnormal distributions (Crawford et al., 2015). We further variated the thresholds to the $80^{\text {th }}$ and $20^{\text {th }}$ percentiles, similar to the approach proposed by Ordanini, Parasuraman and Gaia (2014). These results are represented in Table 2 . Where differences between the $75^{\text {th }}$ and $80^{\text {th }}$ percentile or the $25^{\text {th }}$ and $20^{\text {th }}$ percentile were significant, we tested our model with the different thresholds to ensure that the results were robust.

\subsection{Constructs validity}

We used confirmatory factor analysis to evaluate the validity of our measurement model. Specifically, to test the relationship between the measurement items and their respective constructs, we evaluated constructs' convergent validity (Hair et al., 2006). We have used three criteria to evaluate the convergent validity: factor loadings, average variance extracted, and reliability. First, factor loading for each measurement item needs to be significant and above 0.5 (ideally 0.70 ). Additionally, the bootstrapped confidence intervals (bias corrected, at a 95\% level) should not include zero. Second, each construct's average variance extracted should be 0.5 or higher. Finally, construct reliability indicators (i.e., Cronbach's alpha and Composite reliability) must be 0.7 or higher (with a construct reliability between 0.6 and 0.7 also acceptable provided other indicators of construct validity are good) (Hair et al., 2006).

Appendix A illustrates values including factor loadings, their significance level, and confidence intervals for the measurement items. The constructs' average variance extracted along with their reliability indicators are detailed in Table 3. At the construct level, convergent 
validity is supported because all average variance extracted values are higher than 0.5 (except for SEI). Similarly, all reliability indicators are acceptable (except for SOC and SEI).

\section{INSERT TABLE 3 ABOUT HERE}

At the measurement item level, the factor loadings of all items are significant and above the acceptable threshold, except hum1 (0.165n.s.), com5 (0.492n.s.), soc3 (0.410n.s.), and sei3 $\left(0.478^{*}\right)$. To deal with such items, it is commonly advised to remove them from the analysis. However, we have carefully reviewed these four items and decided against such a procedure. Particularly, following Hair et al. (2006), we examined the content validity of the identified items. Given the acceptable reliability and average variance extracted, we chose to keep hum1 measuring the highest level of education obtained by the founder in our model as an important and often-used measure for human capital in prior entrepreneurship studies (e.g., Rauch \& Rijsdijk, 2013). Similarly, com5 measuring market-oriented competencies is a core element in the operationalization of competencies (Danneels, 2008; Kaleka, 2002). Thus, given the strong construct-level validity measures, we chose to keep com5 in the model. The low factor loadings of soc3 and sei3 explain the borderline measures for construct-level composite reliability. However, removing soc3 will provide an incomplete operationalization of social capital by overlooking the capital provided by external partners (beyond family and friends) (Stam et al., 2014). Equally, the elimination of sei3 representing the changes in marketing activities of the venture leads to an inadequate view of venture seizing capabilities. Hence, both soc 3 and sei3 were kept in the model. 


\section{Data analysis and results}

\subsection{Configurational analysis}

QCA elaborates theory by identifying necessary and/or sufficient conditions for an outcome of interest to occur. Accordingly, necessary and sufficient analysis establishes complex causal statements that are conjunctural in that they employ multiple conditions to produce outcomes of interest jointly. Hence, the outcome of the configurational analysis are configurations of factors rather than the individual factors themselves (Fiss, 2007; Misangyi et al., 2017).

\subsection{Necessity analysis}

A necessary condition is one that is required for a particular outcome to occur (Schneider \& Wagemann, 2012). The causal claim being made is that the outcome of interest is never present when the necessary condition is absent. All individual conditions with membership scores consistently greater than or equal to outcome scores pass the test of necessity. We found that in stable environments, resources, competencies, and sensing are necessary conditions. Under the assumption of a dynamic environment, only competencies and sensing appeared to be necessary conditions. Technically speaking, these conditions exceed the threshold of 0.80 for causal necessity; however, they are only necessary for the outcome to occur but are not sufficient. Thus, we conducted a further sufficiency analysis with the purpose of identifying the complex combinations of single conditions that cause the outcome to occur.

\subsection{Sufficiency analysis}

A particular condition or a combination of conditions are sufficient if the occurrence of the condition(s) is always accompanied by the outcome (Ragin, 2008). In fact, sufficiency implies that these conditions or their combinations are a subset of the outcome. The sufficiency of a combination of conditions for observing the outcome is shown if membership scores in the 
proposed combinations are consistently less than or equal to the membership in the outcome. At this analysis stage, we made use of the truth table and the Quine-McCluskey algorithm for the Boolean minimization. This algorithm maps the logically possible and empirically occurring combinations of capabilities or fuzzy sets under study (Duşa \& Thiem, 2015).

Table 4 shows two sets of configurations, one for stable and one for dynamic environments. We follow the notation applied by Fiss (2011), where “•” represents conditions that were central to the occurrence of the outcome. Those conditions, the presence of which are not central for the outcome to occur, are denoted by " $O$ " representing their absence. Finally, " $\mathrm{x}$ " indicates that a given condition is not causally related to the outcome.

\section{INSERT TABLE 4 ABOUT HERE}

QCA provides three types of solutions based on the manner in which they apply counterfactual analysis: complex, parsimonious, and intermediate. A counterfactual analysis takes into account that there are logically possible configurations for which no cases exist (Soda \& Furnari, 2012). Whereas the complex solution avoids using any counterfactual cases, the parsimonious solution permits the use of any remainder that will yield simpler (or fewer) configurations. The intermediate solution only uses the remainders that survive counterfactual analysis based on theoretical and substantive knowledge (Ragin, 2008; Schneider \& Rohlfing, 2016). Following Ragin's (2008) recommendation, we displace the intermediate solution as the main point of reference for interpreting the QCA results.

We also disclose the consistencies and coverages for the overall solutions, as well as for each individual configuration. We set the thresholds for consistency $(0.80)$ and the frequency of cases (two cases minimum) per configuration. Consistency specifies "how closely a perfect subset relation is approximated" (Ragin, 2008, p. 44). The coverage measures support for a researcher 
in determining which percentage of the outcome is covered through a configuration whereby solution coverage (indicating how much is covered by the solution term), raw coverage (indicating which share of the outcome is explained by a certain alternative path), and unique coverage (indicating which share of the outcome is exclusively explained by a certain alternative path) are of relevance (Schneider \& Wagemann, 2012).

We therefore established three configurational paths for venture formation in each stable and dynamic environment (Table 4). The overall solution coverage for the three pathways in stable environments is 0.362 and for the three pathways in dynamic environments is 0.338 . Our results are consistent (stable environments $=0.903$, dynamic environments $=0.897$ ). Both together indicate sufficient coverage and consistency.

\subsection{Supplement analysis}

We tested the goodness of the QCA procedure by performing several robustness checks (Cooper \& Glaesser, 2016). In particular, we tested proportional reduction in inconsistency (PRI) because skewed set membership is a threat in QCA. In addition to using alternative thresholds to detect changes in the configurations, we applied the PRI approach to assess the existence of simultaneous subset relations. Their presence indicates a logical contradiction because such relations would be expressed by a condition having high consistency as a sufficient condition for the presence as well as the absence of the outcome (i.e., a condition satisfies the formula $\mathrm{x} \leq \mathrm{y}$ and $\mathrm{x} \leq \sim \mathrm{y}$ ) (Ragin, 2008). Results indicate weak but sufficient measures. We further assessed necessary conditions determining whether any of the seven conditions can be regarded as necessary for causing the outcome by applying a subsequent analysis (Dul, 2016). Therefore, we used the approach provided by the fs/QCA 3.0 software. This second analysis confirms our prior results, implying that our findings are reliable according to commonly used test procedures 
(Skaaning, 2011). Finally, we altered the outcome from presence to absence (e.g., conceptually exchanging formal registration with failing to register the business formally). With this procedure, we were able to ensure that no configuration is relevant for both the presence and absence of the outcome.

\section{New venture capability configurational archetypes}

Based on the common patterns of capabilities observed in the alternative configurations, we identify four distinct venture archetypes: capability driven, resource driven, bricoleur, and agile (Table 4). Below, we discuss these four archetypes sequentially.

\subsection{Capability-driven ventures}

In stable environments, capability-driven ventures are successfully formed as a result of the combination of high levels of human capital, ordinary capabilities, and dynamic capabilities (i.e., Configuration I). Our findings in configuration I are consistent with research showing that the founder's human capital (e.g., Cassar, 2014; Grichnik et al., 2014) as well as the venture's resources (Haynie et al., 2009; Wood \& Williams, 2014) and competencies (Dimov, 2010) play a significant role in the founder's evaluation of the new venture idea and entrepreneurial activities underpinning new venture formation. Although our findings in Configuration I corroborate these conclusions, our results also extend previous work by clarifying the role of founders' social capital and managerial cognition as well as ventures' dynamic capabilities in the formation of new ventures where human capital, resources, and competencies are present.

First, our results suggest that the absence or presence of social capital and managerial cognition does not determine the formation of capability-driven ventures. Social capital and managerial cognition will only contribute to new venture formation through generating ordinary and dynamic capabilities (Samuelsson \& Davidsson, 2009; Vilanova \& Vitanova, 2019), which 
could be generated by human capital on its own (Rotefoss \& Kolvereid, 2005). In addition to its contribution towards creating ordinary and dynamic capabilities, human capital also drives new venture formation through its impact on the self-focused evaluation of the new venture idea (i.e., a quality lacking for social capital and managerial cognition) (Ardichvili et al., 2003; Cassar, 2014). Therefore, where human capital is present, the existence of social capital and managerial cognition is not a necessary factor in new venture formation.

Second, interestingly, the existence of sensing and seizing capabilities appears to be a condition for the formation of capability-driven ventures. In stable environments, new ventures engage in causation processes and rely on identifying and consequently acquiring or developing ordinary capabilities that could generate the desired outcomes with a high degree of certainty (Fisher, 2012; Jiang \& Tornikoski, 2019). Although in these settings new ventures do not need dynamic capabilities to respond to environmental changes (Jiang \& Tornikoski, 2019), they still require sensing capabilities to benchmark successful resources and competencies in the market as well as seizing capabilities to reconfigure the initial ordinary capabilities accordingly (Lisboa et al., 2016; Newbert, 2005). Hence, capability-driven ventures are formed in the presence of dynamic capabilities. Hence, we propose the following:

Proposition 1: In stable environments, a high level of a venture's resources, competencies, sensing, and seizing combined with a high level of the founder's human capital will result in successful formation of the venture.

\subsection{Resource-driven ventures}

In both stable and dynamic environments, resource-driven ventures are formed as a result of a high level of resources, competencies, and sensing capabilities, but a low level of seizing and dynamic managerial capabilities (i.e., Configurations II and IV). In contrast to capability-driven 
ventures that require generating and updating resources and competencies in the early stages of new venture formation, resource-driven ventures generally start with a set of ready-made valuable and unique ordinary capabilities. This proposal is consistent with the resource-based view (Barney, 1991), where the evaluation of opportunity relatedness and attractiveness relies on the venture underpinning valuable, rare, inimitable, and nonsubstitutable resources (Haynie et al., 2009). Indeed, the viability of resource-driven ventures is merely evaluated based on ordinary capabilities, leading to successful formation of these ventures. Furthermore, our results reveal that resource-driven ventures require sensing capabilities to identify environmental changes. However, given the value of initial ordinary capabilities, these ventures do not reconfigure resources and competencies through seizing capabilities. Indeed, resource-driven ventures engage mainly in causation processes and seek to protect the valuable resources that they already own or control by avoiding the identified changes (Jiang \& Tornikoski, 2019).

Our results further reveal the absence of dynamic managerial capabilities in idea-driven ventures. Founders with a high level of human capital, social capital, and/or managerial cognition are inclined to generate resources and competencies themselves rather than acquiring often expensive and difficult-to-customize ready-made ordinary capabilities. However, we find that, in dynamic environments, resource-driven ventures may be formed in the presence of human capital. We suggest that these ventures would benefit from the founder's human capital in the evaluation of new venture ideas rather than the further generation of ordinary capabilities. Specifically, in these environments where ventures with a similar set of capabilities may not exist, the evaluation of the new venture idea requires specialized knowledge and experience (Wood \& Mckinley, 2017). Thus, we propose the following: 
Proposition 2: In both stable and dynamic environments, a high level of a venture's resources, competencies, and sensing combined with a low level of the venture's seizing and founder's human capital (only in stable environments), social capital, and managerial cognition will result in successful formation of the venture.

\subsection{Bricoleur ventures}

Our results suggest that ventures with a high level of competencies and sensing capabilities and a low level of seizing and dynamic managerial capabilities are successfully formed in dynamic environments (i.e., Configuration VI). We label these ventures that are not formed as a result of a high level of resources (often associated with the condition of resource scarcity) or dynamic managerial capabilities as bricoleur ventures. Such ventures engage in a number of creative processes to maximize their output given the limited available resources they own or can generate through dynamic managerial capabilities (Baker \& Nelson, 2005; Fisher, 2012). These processes are different from causation and effectuation processes in that they rely on creativity to define new causal relationships between means and outcomes.

Our results suggest that bricoleur ventures are formed merely based on the competencies generated as a result of bricolage processes. Although bricoleur ventures largely rely on internal creativity, improvisation, and trial and error rather than discovery processes (Adomako, Opoku, \& Frimpong, 2018; Welter et al., 2016), over time these ventures start routinizing what they come across as effective, leading to the development of competencies (Fisher, 2012). The established competencies will endorse the viability of the new venture. Specifically, this is a valid strategy where the lack of ventures with similar resources and competencies make the evaluation of new venture ideas difficult (Wood \& Mckinley, 2017). Furthermore, our findings demonstrate that bricoleur ventures are formed in the presence of sensing capabilities and the 
absence of seizing capabilities. Indeed, bricoleur ventures require sensing capabilities not to discover changes or new opportunities in the environment (to then address them through their seizing capabilities), but to learn about the potential of their available resource as well as the ways through which ventures create value. Hence, the outcome of sensing activities will be used to position the new venture in the market rather than to update or create new resources (i.e., seizing).

Bricolage processes are not rational; they do not involve the evaluation of discovered opportunities or rational actions towards profit-maximization (Welter et al., 2016). Therefore, knowledge and experience (i.e., human capital) or access to existing resources in the market through external relationships (i.e., social capital) are not required to form bricoleur ventures. Managerial cognition that relies on the existing knowledge in the market largely captured through building external relationships or intelligence gathering (Levine et al., 2017; Huynh et al., 2017) is also not associated with creating a new form of knowledge and hence is unnecessary in the formation of bricoleur ventures. We propose the following:

Proposition 3: In dynamic environments, a high level of a venture's competencies and sensing combined with a low level of the venture's seizing and founder's dynamic managerial capabilities will result in successful formation of the venture.

\subsection{Agile ventures}

Our results suggest that new ventures are successfully formed as a result of a high level of ordinary capabilities, dynamic capabilities, and managerial cognition as well as a low level of social capital in both stable and dynamic environments (i.e., Configurations III and V). We label these ventures that rely on simultaneously developing multiple sets of resources and competencies that often reside in different areas of specialization to gain a competitive advantage 
as agile ventures. Specifically, such ventures differ from capability-driven ventures in that they gain competitive advantage by the variety and speed of their actions, which rely on different sets of ordinary capabilities. This phenomenon is reflected in the notion of competitive aggressiveness (i.e., the intensity of a venture's efforts to outperform industry rivals, Lumpkin \& Dess, 2001), where firms maximize their benefit through the speed and volume of competitive actions (Nadkarni, Chen, \& Chen, 2016). Specifically, agile ventures benefit from their strong sensing capabilities to explore external resources and competencies that could then be seized to enhance the variety of strategic actions required for their competitive aggressiveness (Larrañeta, Zahra, \& González, 2012).

Agile ventures benefit from a high level of managerial cognition but, simultaneously, a low level of social capital. These ventures need to be flexible to be able to constantly create different sets of resources and competencies. Hence, the founders do not form strong social capital that will limit them to the development of only a specific set of ordinary capabilities, the divestment of which will be challenging due to the presence of strong relationships. They rather build on their managerial cognition in channeling resources and competencies through loosely coupled sources that enhance their flexibility in developing multiple different capabilities (Dai, Goodale, Byun, \& Ding, 2018). Furthermore, our results show that the presence or absence of human capital do not impact the formation of agile ventures. While a high level of human capital in the form of founders' knowledge and skills does not limit venture flexibility in the manner that social capital does, the presence of human capital, which often revolves around one area of specialization, is not instrumental in helping agile ventures to develop multiple sets of capabilities. 
The competitive aggressiveness strategy is more productive in hypercompetitive settings where intense and rapid competitive moves prevail (Chen, Katila, \& Mcdonald, 2010; Larrañeta et al., 2014|). Although it was expected for agile ventures to be formed only in dynamic environments, our results show that they are also successfully formed in stable environments. We suggest that this unexpected result can be explained by cultural factors associated with Australian entrepreneurs. Watson, Dada, Wright, and Perrigot (2019) documented that the national culture of Australia is relatively masculine and thus positively associated with competitive aggressiveness. Hence, we propose the following:

Proposition 4: In both stable and dynamic environments, a high level of a venture's resources, competencies, sensing, and seizing combined with a high level of the founder's managerial cognition and a low level of the founder's social capital will result in successful formation of the venture.

\section{Conclusions}

Our study has sought to extend understanding of the role of capabilities in venture success by offering alternative configurations of distinct ordinary capabilities, dynamic capabilities, and dynamic managerial capabilities that lead to successful new venture formation in both stable and dynamic environments. Specifically, we uncover four unique archetypes of ventures, the formation of which is shaped as a result of specific combinations of capabilities: capability driven, resource driven, bricoleur, and agile. Our configurational approach reveals that different ventures can achieve the same result through various unique combinations of capabilities. In doing so, this study contributes to the entrepreneurship literature in several ways. These contributions are elaborated below, and a summary positioning our work in relation to extant literature is presented in Table 5 . 


\section{INSERT TABLE 5 ABOUT HERE}

First, we demonstrate that a single constituent of ordinary, dynamic, or dynamic managerial capabilities by itself (as investigated in previous studies, e.g., Coad et al., 2013; Dimov, 2010; Newbert \& Tornikoski, 2013) is not sufficient to explain venture formation. In particular, our work contributes to the extant entrepreneurship literature investigating venture ordinary capabilities (e.g., Wood \& Williams, 2014), dynamic capabilities (e.g., Lisboa et al., 2016), or dynamic managerial capabilities (Townsend \& Busenitz, 2015) by showing that these capabilities, in combination, lead to the formation of new ventures. Furthermore, whereas the interactions of founder and venture capabilities have remained largely unexplored in the literature, our research clarifies the role of founders' dynamic managerial capabilities in venture formation in light of ventures' ordinary and dynamic capabilities.

Second, our study sheds light on the role of dynamic capabilities in new venture formation by clarifying the nature and function of these capabilities in different venture archetypes. Specifically, although sensing capabilities appeared to play a crucial role in new venture formation in all observed configurations, the function of these capabilities differs in various venture archetypes. Sensing capabilities are set to benchmark other ventures possessing similar ordinary capabilities in capability-driven ventures, whereas they aim to identify environmental changes in resource-driven ventures. Alternatively, although these capabilities seek to discover resource and competency development opportunities in agile ventures, they also learn about the potential and position of venture available resources and competencies in bricoleur ventures. Furthermore, our study suggests that seizing capabilities extend and update the existing ordinary capabilities in capability-driven ventures; in contrast, they serve to utilize multiple value creation opportunities in agile ventures. 
Third, our study advances understanding of the role of environmental dynamism in defining how new ventures may benefit from their capability configurations (e.g., Al-Aali \& Teece, 2014; Townsend \& Busenitz, 2015; Zahra et al., 2006). Although resource-driven and agile ventures are observed in both environments, capability-driven and bricoleur ventures are found to be formed only in stable and dynamic environments, respectively. First, capability-driven ventures do not appear to form in dynamic environments where a benchmark of existing valuable resources and competencies does not create a competitive advantage. Additionally, the formation of bricoleur ventures in stable environments that are associated with certainty and risk avoidance appears to be unlikely. Specifically, the completely new set of competencies resulting from the bricolage processes of these ventures are perceived as being risky in these settings.

Finally, we contribute to the extant literature on entrepreneurial behavior models (Fisher, 2012; Welter et al., 2016) by clarifying the manner in which new ventures develop multiple successful configurations of capabilities that lead to new venture formation. Although the variations in capability configurations of capability- and resource-driven ventures can be explained by their different behaviors resulting from their engagement in causation (in stable environments) or effectuation (in dynamic environments) processes (Sarasvathy, 2001), we have also found two understudied venture archetypes (i.e., bricoleur and agile ventures), the behavior of which with respect to capability development cannot be explained by these conventional behavioral models. In particular, our study has identified bricoleur ventures with behavior that can be explained by a more recent model of entrepreneurial behavior explicating new venture strategies under conditions of resource scarcity (i.e., bricolage, Fisher, 2012; Welter et al., 2016). We further suggest that these ventures often rely on the founders' creativity in creating new forms of resources and competencies, a missing component in the existing conceptualization of 
dynamic managerial capabilities (human capital, social capital, and managerial cognition, Townsend \& Busenitz, 2015). Furthermore, we propose a new behavioral model through which agile ventures emerge, relying on speed and variety of competitive actions as a key strategy in achieving a competitive advantage. Although some aspects of this model can be explained by existing concepts such as strategic flexibility (Dai et al., 2018) and the variety of strategic actions (Larrañeta et al., 2012), further research is required to identify the core elements of this new behavioral model. 


\section{References}

Adomako, S., Opoku, R. A., \& Frimpong, K. (2018). Entrepreneurs' improvisational behavior and new venture performance: Firm-level and institutional contingencies. Journal of Business Research, 83,10-18.

Al-Aali, A., \& Teece, D. J. (2014). International entrepreneurship and the theory of the (LongLived) international firm: A capabilities perspective. Entrepreneurship Theory and Practice, 38 (1), 95-116.

Adler, P. S., \& Kwon, S.-W. (2002). Social capital: Prospects for a new concept. Academy of Management Review, 27(1), 17-40.

Amit, R., \& Schoemaker, P. J. H. (1993). Strategic assets and organizational rent. Strategic Management Journal, 14(1), 33-46.

Amit, R., \& Han, X. (2017). Value creation through novel resource configurations in a digitally enabled world. Strategic Entrepreneurship Journal, 11(3), 228-242.

Ardichvili, A., Cardozo, R., \& Ray, S. (2003). A theory of entrepreneurial opportunity identification and development, Journal of Business Venturing, 18(1), 105-123.

Arend, R. J. (2014). Entrepreneurship and dynamic capabilities: How firm age and size affect the 'capability enhancement-SME performance' relationship. Small Business Economics: An Entrepreneurship Journal, 42(1), 33-57.

Baker, T., \& Nelson, R. E. (2005). Creating something from nothing: Resource construction through entrepreneurial bricolage. Administrative Science Quarterly, 50(3), 329-366.

Bammens, Y., \& Collewaert, V. (2014). Trust between entrepreneurs and angel investors: Exploring positive and negative implications for venture performance assessments. Journal of Management, 40(7), 1980-2008. 
Barney, J. (1991). Firm resources and sustained competitive advantage. Journal of Management, 17(1), 99-120.

Barrales-Molina, V., Bustinza, O. F., \& Gutiérrez-Gutiérrez, L. J. (2013). Explaining the causes and effects of dynamic capabilities generation: A multiple-indicator multiple-cause modelling approach. British Journal of Management, 24(4), 571-591.

Benner, M. J., \& Tushman, M. L. (2003). Exploitation, exploration and process management: the productivity dilemma revisited. The Academy of Management Review, 28(2), 238-256.

Bi, R., Davison, R. M., \& Smyrnios, K. X. (2017). E-business and fast growth SMEs. Small Business Economics: An Entrepreneurship Journal, 48(3), 559-576.

Burke, A., Fraser, S., \& Greene, F. J. (2010). The multiple effects of business planning on new venture performance. Journal of Management Studies, 47(3), 391-415.

Cassar, G. (2014). Industry and startup experience on entrepreneur forecast performance in new firms. Journal of Business Venturing, 29(1), 137-151.

Chen, E. L., Katila, R., \& Mcdonald, R. (2010). Life in the fast lane: Origins of competitive interaction in new vs. established markets. Strategic Management Journal, 31(13), 1527-1547. Coad, A., Frankish, J., Roberts, R., \& Storey, D. (2013). Growth paths and survival chances: An Application of Gambler's Ruin Theory. Journal of Business Venturing, 28(5), 615-632.

Cooper, B., \& Glaesser, J. (2016). Exploring the robustness of set theoretic findings from a large $\mathrm{n}$ fsQCA: An illustration from the sociology of education. International Journal of Social Research Methodology, 19(4), 445-459.

Crawford, G. C., Aguinis, H., Lichtenstein, B., Davidsson, P., \& McKelvey, B. (2015). Power law distributions in entrepreneurship: Implications for theory and research. Journal of Business Venturing, 30(5), 696-713. 
Dai, Y., Goodale, J. C., Byun, G., \& Ding, F. (2018). Strategic flexibility in new high-technology ventures. Journal of Management Studies, 55(2), 265-294.

David, R. J., Sine, W. D., \& Haveman, H. A. (2013). Seizing opportunity in emerging fields: How institutional entrepreneurs legitimated the professional form of management consulting. Organization Science, 24(2), 356-377.

Davidsson, P. (2015). Entrepreneurial opportunities and the entrepreneurship nexus: A reconceptualization. Journal of Business Venturing, 30(5), 674-695.

Davidsson, P., \& Honig, B. (2003). The role of social and human capital among nascent entrepreneurs. Journal of Business Venturing, 18(3), 301-331.

Davidsson, P., Steffens, P., \& Gordon, S. (2011). Comprehensive Australian Study of Entrepreneurial Emergence (CAUSEE): Design, data collection and descriptive results. In K. Hindle, \& K. Klyver (Eds.), Handbook of New Venture Creation Research (pp. 216-250). Cheltenham: Edward Elgar.

Davidsson, P., \& Wiklund, J. (2001). Levels of analysis in entrepreneurship research: Current practice and suggestions for the future. Entrepreneurship Theory and Practice, 25(4), 81-99. Danneels, E. (2008). Organizational antecedents of second-order competencies. Strategic Management Journal, 29(5), 519-543.

De Carolis, D. M., Litzky, B. E., \& Eddleston, K. A. (2009). Why networks enhance the progress of new venture creation: The influence of social capital and cognition. Entrepreneurship Theory and Practice, 33(2), 527-545.

Delmar, F., \& Shane, S. (2004). Legitimating first: Organizing activities and the survival of new ventures. Journal of Business Venturing, 19(3), 385-410. 
Dess, G.G., \& Beard, D. W. (1984). Dimensions of organizational task environments. Administrative Science Quarterly, 29(1), 52-73.

Dimov, D. (2010). Nascent entrepreneurs and venture emergence: Opportunity confidence, human capital and early planning. Journal of Management Studies, 47(6), 1123-1153.

Drnevich, P. L., \& Kriauciunas, A. P. (2011). Clarifying the conditions and limits of the contributions of ordinary and dynamic capabilities to relative firm performance. Strategic Management Journal, 32(3), 254-279.

Dul, J. (2016). Identifying single necessary conditions with NCA and fsQCA. Journal of Business Research, 69(4), 1516-1523.

Duşa, A., \& Thiem, A. (2015). Enhancing the minimization of Boolean and multivalue output functions with eQMC. The Journal of Mathematical Sociology, 39(2), 92-108.

Fisher, G. (2012). Effectuation, causation, and bricolage: A behavioral comparison of emerging theories in entrepreneurship research. Entrepreneurship Theory and Practice, 36(5), 1019-1051. Fiss, P. C. (2007). A set-theoretic approach to organizational configurations. Academy of Management Review, 32(4), 1180-1198.

Fiss, P. C. (2011). Building better causal theories: A fuzzy set approach to topologies in organization research. Academy of Management Journal, 54(2), 393-420.

Glaesser, J., \& Cooper, B. (2014). Exploring the consequences of a recalibration of causal conditions when assessing sufficiency with fuzzy set QCA. International Journal of Social Research Methodology, 17(4), 387-401.

Girod, S. J. G., \& Whittington, R. (2017). Reconfiguration, restructuring and firm performance: Dynamic capabilities and environmental dynamism. Strategic Management Journal, 38(5), $1121-1133$ 
Grichnik, D., Brinckmann, J., Singh, L., \& Manigart, S. (2014). Beyond environmental scarcity: Human and social capital as driving forces of bootstrapping activities, Journal of Business Venturing, 29(2), 310-326.

Gruber, M. (2007). Uncovering the value of planning in new venture creation: A process and contingency perspective. Journal of Business Venturing, 22(6), 782-807.

Gruber, M., Kim, S. M., \& Brinckmann, J. (2015). What is an attractive business opportunity? An empirical study of opportunity evaluation decisions by technologists, managers, and entrepreneurs. Strategic Entrepreneurship Journal, 9(3), 205-225.

Hair, J. F. Jr, Black, W. C., Babin, B. J., Anderson, R. E., \& Tatham, R. L. (2006). Multivariate data analysis. Upper Saddle River, NJ: Pearson Prentice Hall.

Hall, J. K., Daneke, G. A., \& Lenox, M. J. (2010). Sustainable development and entrepreneurship: Past contributions and future directions. Journal of Business Venturing, 25(5), $439-448$.

Haynie, J. M., Shepherd, D. A., \& McMullen, J. S. (2009). An opportunity for me? The role of resources in opportunity evaluation decisions. Journal of Management Studies, 46(3), 337-361. Helfat, C. E., \& Winter, S. G. (2011). Untangling dynamic and operational capabilities: Strategy for the (n)ever changing world. Strategic Management Journal, 32(11), 1243-1250.

Helfat, C. E., \& Peteraf, M. (2015). Managerial cognitive capabilities and the microfoundations of dynamic capabilities. Strategic Management Journal, 36(6), 831-850.

Helfat, C. E., \& Martin, J. A. (2015). Dynamic managerial capabilities: Review and assessment of managerial impact on strategic change. Journal of Management, 41(5), 1281-1312. 
Helfat, C. E., Finkelstein, S., Mitchell, W., Peteraf, M. A., Singh, H., Teece, D. J., \& Winter, S. (2007). Dynamic capabilities: Understanding strategic change in organizations, Malden: Blackwell Publishing.

Huynh, T., Pattona, D., Arias-Arandab, D., \& Molina-Fernándezb, L. M. (2017). University spin-off's performance: Capabilities and networks of founding teams at creation phase. Journal of Business Research, 78, 10-22.

Jiang, Y., \& Tornikoski, E. T. (2019). Perceived uncertainty and behavioral logic: Temporality and unanticipated consequences in the new venture creation process. Journal of Business Venturing, 34(1), 23-40.

Kaleka, A. (2002). Resources and capabilities driving competitive advantage in export markets: guidelines for industrial exporters. Industrial Marketing Management, 31(3), 273-283.

Karna, A., Richter, A., \& Riesenkampff, E. (2016). Revisiting the role of environment in the capabilities-financial performance relationship: A meta-analysis, Strategic Management Journal., 37(6), 1154-1173.

Khelil, N. (2016). The many faces of entrepreneurial failure: Insights from an empirical taxonomy. Journal of Business Venturing, 31(1), 72-94.

Ko, E. J., \& McKelvie, A. (2018). Signalling for more money: The roles of founders' human capital and investor prominence in resource acquisition across different stages of firm development. Journal of Business Venturing, 33(4), 438-454.

Kor, Y. Y., Mahoney, J. T., \& Michael, S. C. (2007). Resources, capabilities and entrepreneurial perceptions. Journal of Management Studies, 44(7), 1187-1212. 
Kollmann, T., \& Stöckmann, C. (2014). Filling the entrepreneurial orientation-performance gap: The mediating effects of exploratory and exploitative innovations. Entrepreneurship Theory and Practice, 38(5), 1001-1026.

Laamanen, T., \& Wallin, J. (2009). Cognitive dynamics of dynamic development paths. Journal of Management Studies, 46(6), 950-981.

Larrañeta, B., Zahra, S. A., \& González, J. L. G. (2012). Enriching strategic variety in new ventures through external knowledge. Journal of Business Venturing, 27(4), 401-4013.

Larrañeta, B., Zahra, S. A., \& González, J. L. G. (2014). Strategic repertoire variety and new venture growth: The moderating effects of origin and industry dynamism. Strategic Management Journal, 35(5), 761-772.

Lee, C., Lee, K., \& Pennings, J. M. (2001). Internal capabilities, external networks, and performance: A study on technology-based ventures. Strategic Management Journal, 22(6), $615-640$.

Levine, S. S., Bernard, M., \& Nagel, R. (2017). Strategic intelligence: The cognitive capability to anticipate competitor behavior. Strategic Management Journal, 39(2), 2390-2423.

Lichtenstein, B. B., Carter, N. M., Dooley, K. J., \& Gartner, W. B. (2007). Complexity dynamics of nascent entrepreneurship. Journal of Business Venturing, 22(2), 236-261.

Linder, C., Lechner, C., \& Petzl, F. (2019). Many roads lead to Rome: How human, social, and financial capital are related to new venture survival. Entrepreneurship Theory and Practice, (DOI: $10.1177 / 1042258719867558)$.

Lisboa, A., Skarmeas, D., \& Saridakis, C. (2016). Entrepreneurial orientation pathways to performance: A fuzzy-set analysis. Journal of Business Research, 69(4), 1319-1324. 
Lumpkin, G. T., \& Dess, G. G. (2001). Linking two dimensions of entrepreneurial orientation to firm performance: The moderating role of environment and industry life cycle. Journal of Business Venturing, 16(5), 429-451.

Maggetti, M., \& Levi-Faur, D. (2013). Dealing with Errors in QCA. Political Research Quarterly, 66(1), 198-204.

McKelvie, A., \& Davidsson, P. (2009). From resource base to dynamic capabilities: An investigation of new firms. British Journal of Management, 20(S1), S63-S80.

McKnight, B., \& Zietsma, C. (2018). Finding the threshold: A configurational approach to optimal distinctiveness. Journal of Business Venturing, 33(4), 493-512.

Meyer, A. D., Tsui, A. S., \& Hinings, C. R. (1993). Configurational approaches to organizational analysis. Academy of Management Journal, 36(6), 1175-1195.

Miozzo, M., \& DiVito, L. (2018). Productive opportunities, uncertainty, and science-based firm emergence. Small Business Economics: An Entrepreneurship Journal, https://doi.org/10.1007/s11187-018-0033-5.

Misangyi, V. F., Greckhamer, T., Furnari, S., Fiss, P. C., Crilly, D., \& Aguilera, R. (2017). Embracing causal complexity: The emergence of a neo-configurational perspective. Journal of Management, 43(1), 255-282.

Mousa, F.T., \& Reed, R. (2013). The impact. Of slack resources on high-tech IPOs. Entrepreneurship Theory and Practice, 37(5), 1123-1147.

Nadkarni, S., Chen, T., \& Chen, J. (2016). The clock is ticking! Executive temporal depth, industry velocity, and competitive aggressiveness. Strategic Management Journal, 37(6), 11321153. 
Nambisan, S., \& Baron, R. A. (2013). Entrepreneurship in innovation ecosystems:

Entrepreneurs' self-regulatory processes and their implications for new venture success.

Entrepreneurship Theory and Practice, 37(5), 1071-1097.

Newbert, S. L. (2005). New firm formation: A dynamic capability perspective. Journal of Small Business Management, 43(1), 55-77.

Newbert, S. L. (2007). Empirical research on resource-based view of the firm: An assessment and suggestions for future research. Strategic Management Journal, 28(2), 121-146.

Newbert, S. L., \& Tornikoski, E. T. (2013). Resource acquisition in the emergence phase:

Considering the effects of embeddedness and resource dependence. Entrepreneurship Theory and Practice, 37(2), 249-280.

Ordanini, A., Parasuraman, A., \& Rubera, G. (2014). When the recipe is more important than the ingredients. Journal of Service Research, 17(2), 134-149

Qin, F., Wright, M., \& Gao, J. (2017). Are 'sea turtles' slower? Returnee entrepreneurs, venture resources and speed of entrepreneurial entry. Journal of Business Venturing, 32(6), 694-706.

Ragin, C. C. (2008). Redesigning Social Inquiry: Fuzzy Sets and Beyond. Chicago, IL: University of Chicago Press.

Rasmussen, E., Mosey, S., \& Wright, M. (2011). The evolution of entrepreneurial competencies: A longitudinal study of university spin-off venture emergence. Journal of Management Studies, 48(6), 1314-1345.

Rauch, A., \& Rijsdijk, S. A. (2013). The effects of general and specific human capital on longterm growth and failure of newly founded businesses. Entrepreneurship Theory and Practice, 37(4), 923-941. 
Ray, G., Barney, J. B., \& Muhanna, W. A. (2004). Capabilities, business processes, and competitive advantage: Choosing the dependent variable in empirical tests of resource-based view. Strategic Management Journal, 25(1), 23-37.

Reynolds, P. D. (2017). When is a firm born? Alternative criteria and consequences. Business Economics, 52(1), 41-56.

Rotefoss, B., \& Kolvereid, L. (2005). Aspiring, nascent and fledgling entrepreneurs: an investigation of the business start-up process. Entrepreneurship and Regional Development, $17(2), 109-127$.

Samagaio, A., \& Rodrigues, R. (2016). Human capital and performance in young audit firms. Journal of Business Research, 69(11), 5354-5359.

Samuelsson, M., \& Davidsson, P. (2009). Does venture opportunity variation matter? Investigating systematic process differences between innovative and imitative new ventures. Small Business Economics: An Entrepreneurship Journal, 33(2), 229-255.

Sarasvathy, S. D. (2001). Causation and effectuation: Toward a theoretical shift from economic inevitability to entrepreneurial contingency. Academy of Management Review, 26(2), 243-263. Schneider, C. Q., \& Wagemann, C. (2012). Set-theoretic Methods for the Social Sciences: A Guide to Qualitative Comparative Analysis (QCA). Cambridge: Cambridge University Press. Schneider, C. Q., \& Rohlfing, I. (2016). Case studies nested in fuzzy-set QCA on sufficiency: Formalizing case selection and causal inference. Sociological Methods and Research, 45(3), $526-568$.

Semrau, T., \& Hopp, C. (2016). Complementary or compensatory? A contingency perspective on how entrepreneurs' human and social capital interact in shaping start-up progress. Small Business Economics: An Entrepreneurship Journal, 46(3), 407-423. 
Shane, S., \& Stuart, T. (2002). Organizational endowments and the performance of university start-ups. Management Science, 48(1), 154-170.

Skaaning, S. E. (2011). Assessing the robustness of Crisp-set and Fuzzy-set QCA results. Sociological Methods and Research, 40(2), 391-408.

Soda, G., \& Furnari, S. (2012). Exploring the topology of the plausible: Fs/QCA counterfactual analysis and the plausible fit of unobserved organizational configurations. Strategic Organization, 10(3), 285-296.

Stam, W., Arzlanian, S., \& Elfring, T. (2014). Social capital of entrepreneurs and small firm performance: A meta-analysis of contextual and methodological moderators. Journal of Business Venturing, 29(1), 152-173.

Stroe, S., Parida, V., \& Wincent, J. (2018). Effectuation or causation: An fsQCA analysis of entrepreneurial passion, risk perception, and self-efficacy. Journal of Business Research, $89,265-272$.

Teece, D. J., Pisano, G., \& Shuen, A. (1997). Dynamic capabilities and strategic management. Strategic Management Journal, 18(7), 509-533.

Teece, D. J. (2007). Explicating dynamic capabilities: The nature and microfoundations of (sustainable) enterprise performance. Strategic Management Journal, 28(13), 1319-1350. Teece, D. J. (2014). The foundations of enterprise performance: Dynamic and ordinary capabilities in an (economic) theory of firms. Academy of Management Perspectives, 28(4), 328352.

Townsend, D. M., \& Busenitz, L. W. (2015). Turning water into wine? Exploring the role of dynamic capabilities in early-stage capitalization processes. Journal of Business Venturing, 30(2), 292-306. 
Unger, J. M., Rauch, A., Frese, M., \& Rosenbusch, N. (2011). Human capital and entrepreneurial success: A meta-analytical review. Journal of Business Venturing, 26(3), 341-358.

Vilanova, L., \& Vitanova, I. (2019). Unwrapping opportunity confidence: how do different types of feasibility beliefs affect venture emergence? Small Business Economics: An Entrepreneurship Journal, https://doi.org/10.1007/s11187-019-00159-4.

Villani, E., Linder, C., \& Grimaldi, R. (2018). Effectuation and causation in science-based new venture creation: A configurational approach. Journal of Business Research, 83, 173-185.

Wang, C. L., \& Ahmed, P. K. (2007). Dynamic capabilities: A review and research agenda. International Journal of Management Reviews, 9(1), 31-51.

Watson, A., Dada, O., Wright, O., \& Perrigot, R. (2019). Entrepreneurial orientation rhetoric in franchise organizations: The impact of national culture. Entrepreneurship Theory and Practice, 43(4), 751-772.

Welter, C., Mauer, R., \& Wuebker, R. J. (2016). Bridging behavioural models and theoretical concepts: Effectuation and bricolage in the opportunity creation framework. Strategic Entrepreneurship Journal, 10(1), 5-20.

Wilden, R., Devinney, T. M., \& Dowling, G. R. (2016). The architecture of dynamic capability research: Identifying the building blocks of a configurational approach. Academy of Management Annals, 10(1), 997-1076.

Wilhelm, H., Schlömer, M., \& Maurer, I. (2015). How dynamic capabilities affect the effectiveness and efficiency of operating routines under high and low levels of environmental dynamism. British Journal of Management, 26(2), 327-345.

Winter, S. G. (2003). Understanding dynamic capabilities. Strategic Management Journal, 24(10), 991-995. 
Wong, P. K., Ho, Y. P., \& Autio, E. (2005). Entrepreneurship, innovation and economic growth: Evidence from GEM data. Small Business Economics: An Entrepreneurship Journal, 24(3), 335350.

Wood, M. S., \& McKelvie, A. (2015). Opportunity evaluation as future focused cognition: Identifying conceptual themes and empirical trends. International Journal of Management Reviews, 17(2), 256-277.

Wood, M. S., \& Mckinley, W. (2017). After the venture: The reproduction and destruction of entrepreneurial opportunity. Strategic Entrepreneurship Journal, 11(1), 18-35.

Wood, M.S., \& Williams, D. W. (2014). Opportunity evaluation as rule-based decision making. Journal of Management Studies, 51(4), 573-602.

Woodside, A. G. (2013). Moving beyond multiple regression analysis to algorithms: Calling for adoption of a paradigm shift from symmetric to asymmetric thinking in data analysis and crafting theory. Journal of Business Research, 66(4), 463-472.

Zahra, S. A., Sapienza, H. J., \& Davidsson, P. (2006). Entrepreneurship and dynamic capabilities: A review, model and research agenda. Journal of Management Studies, 43(4), $917-$ 955.

Zollo, M., \& Winter, S. G. (2002). Deliberate learning and the evolution of dynamic capabilities. Organization Science, 13(3), 339-351. 


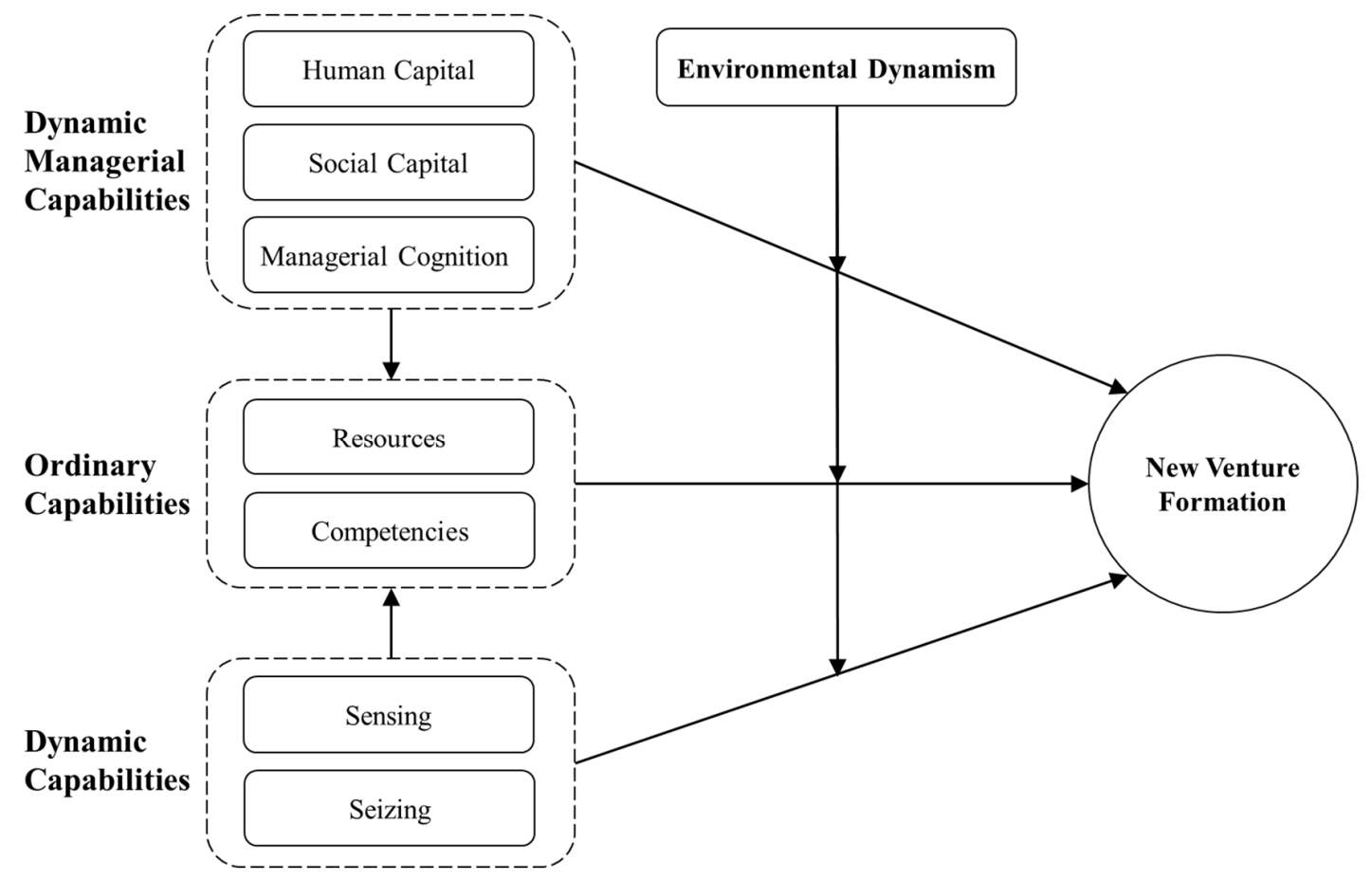

Figure 1. Capabilities and New Venture Formation 
Table 1. Sample characteristics of the founders and new ventures

\begin{tabular}{|c|c|c|c|c|}
\hline Dimension & Mean & S.D. & Frequency & Percent \\
\hline Gender $(\mathrm{m})$ & & & 151 & 50.5 \\
\hline Age & 42.17 & 12.27 & & \\
\hline \multicolumn{5}{|l|}{ Education* } \\
\hline High School - Yr 10 or 12 & & & 6 & 2.0 \\
\hline Diploma (TAFE etc.) & & & 89 & 29.8 \\
\hline Bachelor's degree & & & 66 & 22.1 \\
\hline Higher Uni degree (e.g., Masters, Doctorate) & & & 46 & 15.4 \\
\hline High School - Yr 10 & & & 43 & 14.4 \\
\hline High School - Yr 12 & & & 39 & 13.0 \\
\hline None of these & & & 9 & 3.0 \\
\hline \multicolumn{5}{|l|}{ Experience } \\
\hline Management experience & 11.34 & 10.82 & & \\
\hline Industry experience & 10.17 & 11.98 & & \\
\hline Sales/marketing experience & 1.81 & 0.54 & & \\
\hline Finance experience & 1.93 & 0.81 & & \\
\hline Start-up experience & 1.11 & 1.94 & & \\
\hline \multicolumn{5}{|l|}{ Industry of business* } \\
\hline Retailing & & & 57 & 19.1 \\
\hline Hospitality & & & 11 & 3.7 \\
\hline Consumer services & & & 50 & 16.7 \\
\hline Health, education, or social services & & & 55 & 18.4 \\
\hline Manufacturing & & & 25 & 8.4 \\
\hline Construction & & & 18 & 6.0 \\
\hline Agriculture & & & 10 & 3.3 \\
\hline Mining & & & 4 & 1.3 \\
\hline Wholesale & & & 5 & 1.7 \\
\hline Transportation & & & 3 & 1.0 \\
\hline Utilities & & & 2 & .7 \\
\hline Communications & & & 15 & 5.0 \\
\hline Finance & & & 7 & 2.3 \\
\hline Real Estate & & & 3 & 1.0 \\
\hline Business consulting or service & & & 34 & 11.4 \\
\hline
\end{tabular}

Notes: $\mathrm{N}=299 ; *$ excluding missing cases 
Table 2. Data calibration and calibration rules for set-membership

\begin{tabular}{|c|c|c|c|c|c|c|c|c|}
\hline \multirow[b]{2}{*}{ Variable } & \multirow[b]{2}{*}{$\begin{array}{l}\text { Mean } \\
\text { (s.d.) }\end{array}$} & \multirow[b]{2}{*}{ Min } & \multirow[b]{2}{*}{$\operatorname{Max}$} & \multirow[b]{2}{*}{$\begin{array}{l}\text { Skewness } \\
\text { (std. er.) }\end{array}$} & \multirow[b]{2}{*}{$\begin{array}{l}\text { Kurtosis } \\
\text { (std. er.) }\end{array}$} & \multicolumn{3}{|c|}{ Thresholds for set membership } \\
\hline & & & & & & Fully in & $\begin{array}{l}\text { Cross- } \\
\text { over }\end{array}$ & Fully out \\
\hline FORM & $0.26(0.44)$ & 0.00 & 1.00 & $-0.10(0.12)$ & $2.97(0.13)$ & $1.00(-)$ & - & $0.00(-)$ \\
\hline HUM & $4.68(0.17)$ & 0.00 & 19.00 & $1.28(0.14)$ & $2.31(0.28)$ & $2.22(2.44)$ & 4.03 & $6.09(6.68)$ \\
\hline SOC & $1.78(0.24)$ & 1.00 & 2.67 & $0.27(0.14)$ & $-0.54(0.21)$ & $1.37(1.44)$ & 1.77 & $2.10(2.18)$ \\
\hline $\mathrm{COG}$ & $1.36(0.04)$ & 0.00 & 2.00 & $-0.69(0.18)$ & $-0.91(0.27)$ & $0.40(0.49)$ & 1.41 & $1.69(1.78)$ \\
\hline SEN & $2.66(0.91)$ & 0.00 & 4.00 & $-0.80(0.11)$ & $-0.95(0.19)$ & $0.76(0.88)$ & 1.40 & $3.16(3.93)$ \\
\hline SEI & $1.41(0.07)$ & 0.00 & 4.00 & $0.60(0.12)$ & $0.75(27)$ & $0.13(0.30)$ & 1.20 & $2.41(2.73)$ \\
\hline RES & $9.32(0.15)$ & 3.00 & 15.00 & $-0.49(0.10)$ & $-0.58(0.31)$ & $6.62(7.67)$ & 9.83 & $11.17(11.49)$ \\
\hline COM & $14.52(0.42)$ & 0.00 & 25.00 & $-0.43(0.14)$ & $-1.09(0.26)$ & $8.12(10.63)$ & 15.11 & $21.23(21.81)$ \\
\hline
\end{tabular}

Notes: We applied the fsQCA 3.0 package to calibrate fuzzy set membership degrees. Means are calculated after calibration. For all thresholds, the $75^{\text {th }}$ and $25^{\text {th }}$ percentile was used. The value in brackets represent the $80^{\text {th }}$ and $20^{\text {th }}$ percentile. Where values are significantly different, we performed an alternative analysis to identify changes in the outcome. 
Table 3: Validity criteria on construct level

\begin{tabular}{llll}
\hline Constructs & Cronbach's Alpha & $\begin{array}{l}\text { Composite } \\
\text { Reliability }\end{array}$ & $\begin{array}{l}\text { Average Variance } \\
\text { Extracted }\end{array}$ \\
\hline HUM & 0.636 & 0.640 & 0.520 \\
SOC & 0.624 & 0.571 & 0.555 \\
COG & 0.950 & 0.964 & 0.870 \\
RES & 0.963 & 0.973 & 0.899 \\
COM & 0.944 & 0.946 & 0.544 \\
SEI & 0.618 & 0.548 & 0.312 \\
SEN & 0.848 & 0.898 & 0.689 \\
\hline
\end{tabular}


Table 4. Distinct configurations of ordinary, dynamic, and dynamic managerial capabilities accounting for new venture formation

\begin{tabular}{|c|c|c|c|c|c|c|c|c|c|c|c|c|}
\hline \multirow[b]{2}{*}{ Outcome } & \multirow[b]{2}{*}{ Model } & \multicolumn{3}{|c|}{ Dynamic managerial capabilities } & \multicolumn{2}{|c|}{ Ordinarily capabilities } & \multicolumn{2}{|c|}{$\begin{array}{c}\text { Dynamic } \\
\text { capabilities }\end{array}$} & \multirow[b]{2}{*}{$\begin{array}{c}\text { Raw } \\
\text { coverage }\end{array}$} & \multirow[b]{2}{*}{$\begin{array}{c}\text { Unique } \\
\text { coverage }\end{array}$} & \multirow[b]{2}{*}{ Consistency } & \multirow[b]{2}{*}{$\begin{array}{l}\text { Venture } \\
\text { Archetype }\end{array}$} \\
\hline & & $\begin{array}{l}\text { Human } \\
\text { Capital } \\
\end{array}$ & $\begin{array}{l}\text { Social } \\
\text { Capital }\end{array}$ & $\begin{array}{c}\text { Managerial } \\
\text { Cognition }\end{array}$ & Resources & Competences & Sensing & Seizing & & & & \\
\hline \multicolumn{13}{|c|}{$\mathbf{N}=\mathbf{2 9 9}$} \\
\hline \multicolumn{13}{|c|}{ Stable Environments $(N=137)$} \\
\hline New Venture & I & • & $x$ & $x$ & • & • & • & • & 0.219 & 0.096 & 0.923 & Capability-driven \\
\hline \multirow[t]{5}{*}{ Formation } & II & $\circ$ & $\circ$ & ○ & $\bullet$ & $\bullet$ & $\bullet$ & ० & 0.111 & 0.046 & 0.934 & Resource-driven \\
\hline & III & $x$ & $\circ$ & $\bullet$ & $\bullet$ & $\bullet$ & $\bullet$ & $\bullet$ & 0.192 & 0.054 & 0.913 & Agile \\
\hline & consiste & y cut-off & 0.884 & & & & & & & & & \\
\hline & solution & verage & 0.362 & & & & & & & & & \\
\hline & solution & nsistency & 0.903 & & & & & & & & & \\
\hline \multicolumn{13}{|c|}{ Dynamic Environments $(N=162)$} \\
\hline \multirow{6}{*}{$\begin{array}{l}\text { New Venture } \\
\text { Formation }\end{array}$} & IV & $x$ & o & o & $\bullet$ & $\bullet$ & $\bullet$ & o & 0.249 & 0.070 & 0.949 & Resource-driven \\
\hline & $\mathrm{V}$ & $x$ & $\circ$ & $\bullet$ & $\bullet$ & $\bullet$ & $\bullet$ & $\bullet$ & 0.158 & 0.077 & 0.881 & Agile \\
\hline & VI & ○ & $\circ$ & ○ & $x$ & $\bullet$ & $\bullet$ & ○ & 0.208 & 0.036 & 0.912 & Bricoleur \\
\hline & consiste & y cut-off & 0.871 & & & & & & & & & \\
\hline & solution & verage & 0.338 & & & & & & & & & \\
\hline & solution & nsistency & 0.897 & & & & & & & & & \\
\hline
\end{tabular}

Notes: Central conditions are represented by $\bullet$ (presence), $\circ$ (absence), and $\times$ (indifference). Consistency cut-off $=0.800$ and frequency cut-off $=2$ for the intermediate solution. Accumulated unique coverage 0.100 for stable environment and 0.183 for dynamic environment. 
Table 5. Contributions

\begin{tabular}{|c|c|c|c|}
\hline Constructs & Authors/Year & Literature Findings & Findings of This Study \\
\hline Human Capital & $\begin{array}{l}\text { Ardichvili et al., 2003; Cassar, 2014; } \\
\text { Davidsson \& Honig, 2003; De Carolis } \\
\text { et al., 2009; Dimov, 2010; Grichnik et } \\
\text { al., 2014; Rotefoss \& Kolvereid, 2005; } \\
\text { Samuelsson \& Davidsson, 2009; } \\
\text { Townsend \& Busenitz, 2015; Wood \& } \\
\text { Williams, } 2014\end{array}$ & $\begin{array}{l}\text { The impact of human capital on } \\
\text { entrepreneurial activities and } \\
\text { formal establishment of a new } \\
\text { venture } \\
\text { - The moderating role of human } \\
\text { capital in the relationship } \\
\text { between resources and new } \\
\text { venture idea evaluation }\end{array}$ & $\begin{array}{l}\text { Human capital is instrumental in the formation of } \\
\text { capability-driven ventures even where resources and } \\
\text { competencies are present. However, resource-driven } \\
\text { ventures in stable environments and bricoleur ventures in } \\
\text { dynamic environments are formed in the absence of } \\
\text { human capital. }\end{array}$ \\
\hline Social Capital & $\begin{array}{l}\text { Davidsson \& Honig, 2003; De Carolis } \\
\text { et al., 2009; Grichnik et al., 2014; } \\
\text { Rotefoss \& Kolvereid, 2005; } \\
\text { Samuelsson \& Davidsson, 2009; } \\
\text { Townsend \& Busenitz, } 2015\end{array}$ & $\begin{array}{l}\text { - The impact of social capital on } \\
\text { entrepreneurial activities }\end{array}$ & $\begin{array}{l}\text { Social capital is not a necessary factor in new venture } \\
\text { formation where ordinary capabilities are present. Social } \\
\text { capital can even be a negative factor in the formation of } \\
\text { agile ventures that need flexibility to create multiple sets } \\
\text { of resources and competencies. }\end{array}$ \\
\hline $\begin{array}{l}\text { Managerial } \\
\text { Cognition }\end{array}$ & \multicolumn{2}{|l|}{ Has not been investigated } & $\begin{array}{l}\text { Managerial cognition is crucial in the formation of agile } \\
\text { ventures that require to create multiple sets of resources } \\
\text { and competencies. However, resource-driven and } \\
\text { bricoleur ventures are formed in the absence of } \\
\text { managerial cognition. }\end{array}$ \\
\hline Resources & Wood \& Williams, 2014 & $\begin{array}{l}\text { - The impact of resources on the } \\
\text { evaluation of the new venture } \\
\text { idea }\end{array}$ & $\begin{array}{l}\text { Except in bricoleur ventures, a high level of resources is } \\
\text { necessary for new venture formation. }\end{array}$ \\
\hline Competencies & Dimov, 2010; Rasmussen et al., 2011 & $\begin{array}{l}\text { The impact of competencies on } \\
\text { the evaluation of the new } \\
\text { venture idea }\end{array}$ & $\begin{array}{l}\text { Competencies is an instrumental element determining new } \\
\text { venture formation. In all capability configurations, a high } \\
\text { level of competencies is needed in the formation of new } \\
\text { ventures. }\end{array}$ \\
\hline Sensing & \multirow{2}{*}{$\begin{array}{l}\text { Laamanen \& Wallin, 2009; Lisboa et } \\
\text { al., 2016; Rusmussen et al., } 2011\end{array}$} & \multirow{2}{*}{$\begin{array}{l}\text { - The impact of dynamic } \\
\text { capabilities on the development } \\
\text { of a venture's ordinary } \\
\text { capabilities }\end{array}$} & \multirow{2}{*}{$\begin{array}{l}\text { The impact of dynamic capabilities on new venture } \\
\text { formation is not limited to the creation of resources and } \\
\text { competencies. In capability-driven and agile ventures, a } \\
\text { high level of both sensing and seizing is necessary to form } \\
\text { the new venture. In resource-driven and bricoleur ventures } \\
\text { that are formed in the absence of seizing capabilities, a } \\
\text { high level of sensing is a determining factor. }\end{array}$} \\
\hline Seizing & & & \\
\hline
\end{tabular}


Appendix A

Measurement items used from the Comprehensive Australian Study of Entrepreneurial Emergence (CAUSEE)

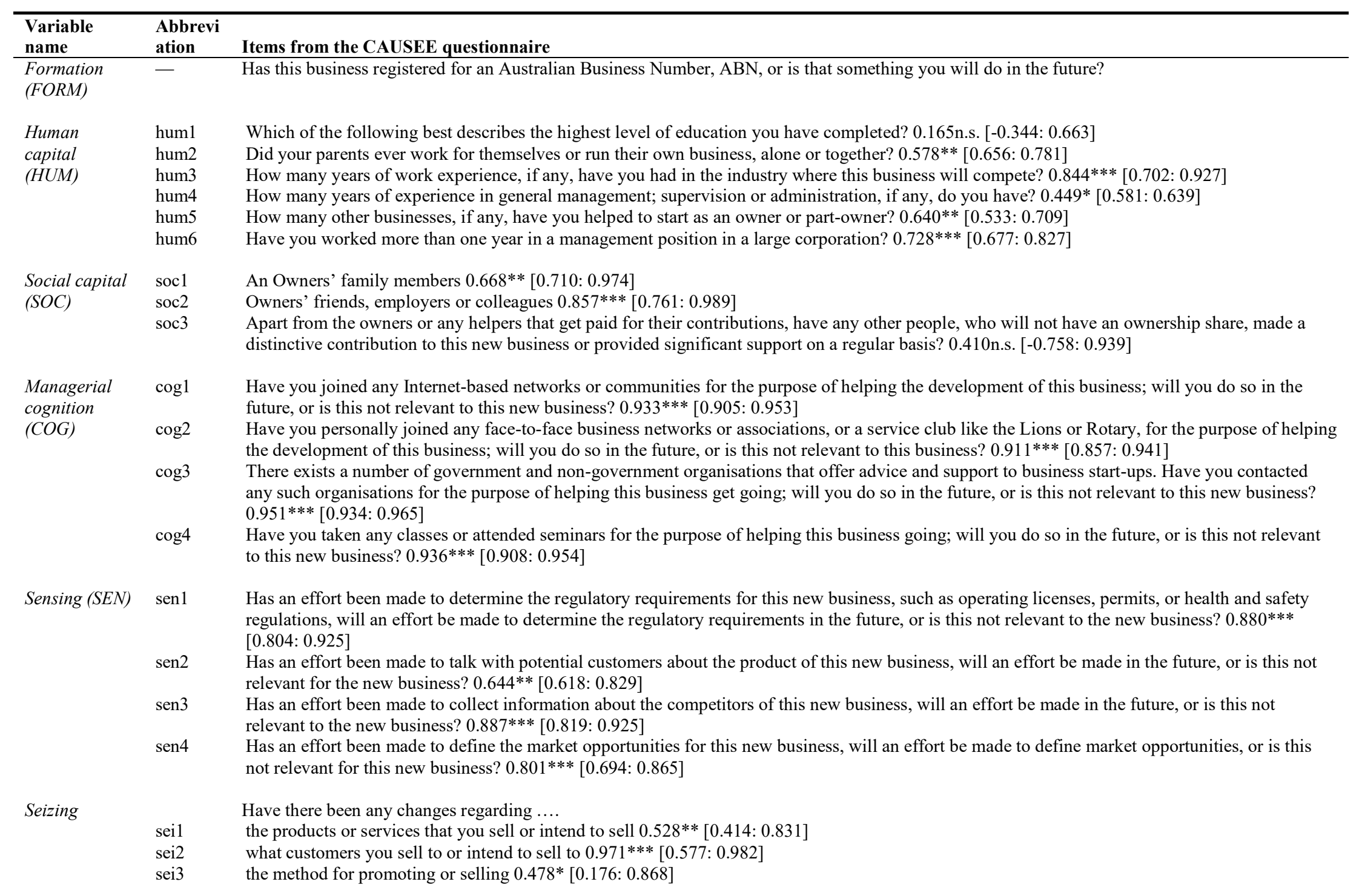


Resources res1 The product/service offerings are selected to very closely match the financial, physical and other resources you have access to $0.949^{* * *}[0.916$ : 